\title{
Sprogets hævn, tankens letsindighed
}

\author{
Stig S ÆTERBAKKEN
}

\section{Prolog: Jeg ser det for mig}

Min første bevidste tanke havde jeg da jeg var mellem tre og fire år. Jeg faldt. Jeg kunne ikke forstå hvad det var, jeg havde aldrig, ikke at jeg var klar over det $\mathrm{i}$ hvert fald, oplevet noget lignende. Dengang boede jeg på Sliberivejen i Lillehammer, midt mellem jernbanestationen og det som dengang var Mesna Æskefabrik, hvor min far havde arbejdet fra han var I6 år, og som i dag er indkøbscentret Strandtorvet med en dobbeltstilk med kirsebær som lysende logo, på en gold odde ud i Lågendeltaet som hvert forår og til langt ud på sommeren fører irgrønt smeltevand ud i Mjøsen og dermed lægger en iskold dæmper på badeforholdene, selv for de mest ihærdige, en paletformet odde som - det er jeg sikker på - består af lige så meget hårdt sammentrampet overskudsflis fra celluloseindustrien som af opdæmmet jord, sten.

Det er to elementer fra dette landskab som danner grundlag for min første bevidste tanke.

Det ene er, at den ni kilometer lange Mesnaelv, efter at have velsignet Lillehammer By med en pitoresk slynget å gennem centrum og et brusende vandfald forbi ude-restauranten Terrassen, det sidste stykke ned mod det som altså dengang var æskefabrikken, løber i rør, for i sin tid at forsyne fabrikken, om ikke helt, så i hvert fald delvis med strøm: elvelejet, med de gådefulde mosbegroede tempelagtige mure, kun et stenkast fra mit barndomshjem, husede med andre ord hverken islagt eller iltert skummende vand, men to enorme sorte naglebesatte panserrør, som uantastet af årstidernes skiften, med deres stoiske symmetriske ro ligesom var det urokkelige fremmedlegeme som holdt det hele på plads: træerne, husene, broerne, plænerne, det menneskeskabte bindeled som måtte til mellem kultur og natur.

Det andet er, at der på denne tid - 1969-1970 - foregik en storstilet grave- og byggevirksomhed i nær sagt alle kvarterer og kanter af lillebyen, stedet var i rivende udvikling, som det hedder, voksede og fornyede sig som en optakt og forberedelse til den norske velstandseksplosion i midten af 70'erne, som om man allerede dengang betragtede oliereserverne $i$ den norske sokkel som uudtømmelige, eller omvendt: at man med en snert af clairvoyance forudså at den olympiske fiktion 25 år senere skulle vende op og ned på både infrastruktur og folkesjæl, med det resultat at nabolaget var omsværmet af lastbiler og gravemaskiner, summende og kravlende ud og ind af store huller og huler, som overdimensionerede insekter på en sydende mødding, og af en eller anden grund var alle disse biler og maskiner gule det er de vel stadig, de fleste af dem, uden at jeg aner hvorfor, og heller aldrig har lagt mærke til om det er et norsk fænomen, denne farve, eller om andre landes eksemplarer af arten også er gule, - og det var selvfølgelig ikke til at undgå at børnene $i$ området, i hvert tilfælde vi drenge, nærede en altopslugende interesse for disse kanariegule monstre, som midt $\mathrm{i}$ deres skrækindjagende vælde havde et mærkeligt forsonende træk, noget nærmest venligt og omsorgsfuldt ved sig, sådan som jeg husker det, som om deres daglige ruter mellem byggepladsen og 'tippen' markerede en grænse, en grænse mellem os og yderverdenen, ligesom de surrede omkring og vogtede denne grænse med deres afskrækkende brøl mens vi spillede fodbold eller trillede omkring i bilerne som min far havde svejset sammen om aftenen 
nede på fabrikken: sådan en gul gravemaskine var det andet af de to elementer som tilsammen udgjorde min første tanke.

Jeg stod i gangen, min mor var i gang med noget ude i køkkenet. Og pludselig så jeg det, lige foran mig, uden at det var der: en gul gravemaskine som stod en smule skævt oppe på to sorte rør.

Efter at have stået $i$ gangen en tid og bare holdt fast i dette billede, gik jeg ud til min mor og forsøgte efter bedste evne at fortælle hende hvad der var sket: jeg husker selvsagt ikke hvad jeg sagde, men det må være lykkedes mig så nogenlunde at sætte ord på det, i hvert tilfælde havde min mor åndsnærværelse nok til at opfatte situationen, og ikke mindst: at undgå at komplicere den unødigt, sådan at hun, mens jeg undrede mig over hvordan $i$ alverden det kunne gå til, gav mig det enkle svar jeg havde brug for: at det jeg havde gjort var at tænke; at når man tænker er det sådan, at man kan se akkurat det man vil for sig, selvom det ikke er der.

Denne forklaring har aldrig helt sluppet sit tag $\mathrm{i}$ mig, på samme måde som billedet af gravemaskinen som balancerer skråt, og kun lige akkurat, på rørene endnu står så klart for mig at jeg kan tegne det, helt nøjagtigt, som det var. Eller som jeg husker det var. I mange år var det væk fra hukommelsen, ikke væk, men dækket til, indtil det blev afsløret igen - jeg husker ikke hvornår, og jeg aner ikke hvorfor - for så at forblive - hvis vi kan forestille os hukommelsen lagdelt, mod større og større dybder - helt $\mathbf{i}$ overfladen af hukommelsen, $i$ erindringens vandskorpe, det vil sige aldrig længere væk fra bevidsthedens rastløse blik end at jeg af og til fảr øje på det, måske flere gange i løbet af en dag, og ikke nødvendigvis som resultat af tankens retning. Pludselig står den der, den gule gravemaskine, på de sorte rør. Og som jeg stadig ser det for mig, har det noget mærkelig distinkt, præcist ved sig, dette billede, som om det var en tanke, før tanken fik sprog. Tilforladeligt, surrealistisk, idyllisk.

\section{Kvalmen}

Næsten hver gang jeg skal begynde på et essay føler jeg mig tom. Helt tom, som om jeg har mistet evnen til at skrive, ikke er i stand til at tænke en eneste tanke til, aldrig mere kommer til at kunne artikulere noget som helst. Det er som om det bliver værre for hver gang, tungere og tungere at komme $\mathrm{i}$ gang. Samtidig har jeg forstået, efterhånden som jeg har lært kvalmen at kende - for tomheden føles først og fremmest som en kvalme - at denne tomhedsfolelse er en nødvendig forberedelse til det som - $i$ bedste fald - skal komme, nærmest det modsatte af inspiration: en slags lammende uvilje mod at gøre netop det jeg har sat mig for at gøre, på samme tid en afsky og en afinagt over for den tanke, eller de tanker, som endnu ikke rigtig har antaget nogen form, og som derfor, fordi de ikke har nogen form endnu, bare kan anes som noget yderst vagt, noget grødet og ubestemmeligt og $\mathrm{i}$ hele sit væsen uappetitligt, fordi det ikke er kommet langt nok endnu til at det kan lade sig gøre at forholde sig til det, være kritisk over for det, spinde videre på det. Lutter resignation. Jeg bliver træt, slap, og modløs. Det byder mig kort sagt imod at begynde.

Før jeg formår at svælge kvalmen i mig og endelig - nærmest modvillig - går i gang, er fristelsen til at give mig i kast med noget andet som regel overvældende, hvad som helst andet, bare ikke dette ene som nu ligger foran mig: skrive et brev, skrive videre på den roman jeg er i gang med, notere nogle punkter til et andet essay - ikke dette - genlæse en bog jeg kender godt, se en film, tage med ungerne ud at kælke, hugge brænde, kaste sne, eller jeg kan fortabe mig $i$ betragtninger over vores kat, fuld af misundelse over dens lade tankeløse livsnyderi hvad som helst, bare ikke dette - anywhere out of this world!

Næsten hver gang jeg skal til at begynde på et essay drømmer jeg om at være popstjerne eller filminstruktør. 


\section{Mareridtet}

Der er et misforhold mellem tanke og ytring som består $\mathrm{i}$ at det som ikke nødvendigvis er klarhed $\mathrm{i}$ tanken bliver klarhed idet sætningen formuleres. Er det derfor det byder mig imod? Formuleringen har skin af noget distinkt, ikke fordi tanken var distinkt, men fordi sproget ikke kan lade være med at være det. På den anden side, hvordan ville det have set ud hvis det havde været muligt at udtrykke kaos? Hvis jeg ved et trylleslag fra en god - eller måske ond fe var blevet $\mathrm{i}$ stand til at formidle det som er i mit hovede, akkurat sådan som det er i hovedet på mig?

Der er det med tankerne, at de kun kan huske sig selv. Vi vågner, sætter os op i sengen, og mareridtet står så klart for os at vi endnu ikke har rystet troen på at det virkelig er sket af os. Straks efter begynder det at aftage. Hvis vi skal kunne huske drømmen, må vi fortælle den til nogen, eller skrive den ned, så hurtigt som muligt, fordi hvert eneste optrin vi ikke omgående rekapitulerer dunster væk, fordamper: ånden slipper ud af flasken. Fortællingen konserverer den: har vi den, har vi den for altid. Vi glemmer drømmen, men husker genfortællingen.

At det hele dermed går fløjten vil kun banalplatonikeren hævde. Genfortællingen gør os ikke kun i stand til at fastholde indtrykket, omend skævt, af drømmen - tanken - den er opstået af, men præciserer den tilmed, bygger videre på dens vage mandat, mutatis mutandis. Det manifeste griber ind i det latente - spøgelser făr kød på kroppen - selv om det, selvfølgelig, aldrig kan favnes helt, og sådan har enhver fortælling, eller tekst, en dobbelthed $i$ forhold til den idé som skabte den, fordi det ikke bare er idéen som nedfælder sig i en takt, men også teksten som skaber idéen ved at uddybe den, eller udvide den, udvikle den til noget den ikke nødvendigvis vidste at den var, eller skulle blive. Formen er ikke givet, men gives.

Det er denne dobbelthed, eller eksistentielle tvetydighed, hvis vi kan kalde den det, jeg finder i en underlig, næsten mystisk sætning hos den slovakiske novelleforfatter Dusan Ducek, som løsrevet fra sam- menhængen - sådan som sæminger nydes bedst kan forstås enten som noget smukt fortrøstningsfuldt, eller ligeså vel, som noget grotesk håbløst: „I hvert menneske er der et menneske."

\section{Hybris}

For en post-Proust litteratur er den blevet noget af et paradigme, denne insisteren på at det er måden hvorpå det siges som bestemmer hvad der bliver sagt. Men det er selvfølgelig ikke kun sådan: der er også en vilje af noget tænkt med i spillet her, en tanke som på forhånd har gjort sig en mening og som forsøger at betvinge sproget til at udtrykke denne mening, selvom formen skulle komme til at forandre den. Den rent viljesstyrede sproglige ytring findes ikke, lige så lidt som der findes nogen automatskrift. Men refleksionen er afhængig af sproget. Sproget skal være godt for at tanken kan være god. Fritænkeri varer kun indtil sætningen gør krav på håndgribelighed. Syntaksen siger: hertil, men ikke længere. Sproget slår tilbage på den som tror sig hævet over dets begrænsninger, det strammer, kvæler tanken i den vilde - blasfemiske? - flugt. Sætningen bliver åsted for viljens kamp med syntaksen.

Sproget løfter tanken frem, sagtens, men forhindrer den også, modsætter sig dens fremfusen, betvinger den med en form for selvjustits: korreks, korrektur, korrosion. Sproget lader sig kun bruge indtil et vist punkt, før dets egne love - grammatiske, fonetiske, poetiske - udøver deres myndighed og låser ytringen $i$ en bestemt stilling: sådan skal den være for at være læselig. Selv den radikale, progesssive tanke bliver korrigeret af noget uhørt: et skønhedshensyn. Den som tænker må overgive sig til sproget, om og om igen, for at komme i balance med sin egen tænknings utålmodighed, trangen til at fylde på, få det ud, komme videre. Tanken - hvilken som helst tanke - må følge sprogets love for det velklingende, som kan presses langt, men ikke helt brydes. En ikke-velklingende tanke er ingen god tanke. Sproget skal kunne bære hvis ræsonnementet skal gøre det samme. Hvis det er den gode vilje, eller en velmenende humanistisk ånd, som sætter ræsonnementet 
igang, er det det æstetiske sprog som bygger det op, det æstetiske sprog som fuldfører det.

Sådan vil sproget, som samler totaliteten af det som angår os, samtidig sprede denne totalitet. Vi kan aldrig helt gribe det som angår os gennem sproget, for det skjuler sig bag påstande som afhænger af hinanden, uden at den helhed som hver af dem henviser til, kommer til syne. Vor opmærksomhed forbliver rettet mod denne helhed, men sætningerne følger hinanden glimtvis og skjuler den for os. Vi kan aldrig se helheden i fuldt lys, og det kan vi ikke rette på. Tværtimod vil det skrevne altid være præget af en slags ondskabsfuld mathed sammenlignet med glansen af den spirende idé som gik forud, ligesom opklaringen af forbrydelsen aldrig kan leve op til det mysterium som gjorde den nødvendig. Ytringen bliver en forringelse, sådan som den fremstår for forfatteren, som en souvenir fra en overvældende rejse, til trods for den genrejsning der finder sted under det hemmelighedsfulde og uforudsigelige stævnemøde hvor ytringen finder den rette læser, fordi konnotationen altid overgår intentionen, fordi læserens - den udkårnes - udbytte af teksten sprænger grænserne for hvad forfatteren på noget tidspunkt har været $i$ stand til at lægge ind $i$ den, netop fordi tanken, $i$ form af en sætning, er løsrevet fra intentionalitet.

I hver tanke er der en tanke. Og måske rummer ethvert menneske sådan en storhed, som kan fornemmes i nogle lykkelig-ulykkelige glimt, men som aldrig kan komme til udtryk som andet end en grimasse, eller en karikatur. Alle er vi klovne idet vi forsøger at leve op til vor egen storhed.

\section{En pludselig frigørende tanke}

Lidt irriteret begynder jeg at skrive. Mod hvad? Mod en uvished, siden jeg endnu ikke ved så forfærdelig meget, ikke om det som skal komme, men heller ikke om den tanke eller idé som danner udgangspunkt for det jeg skal skrive - uanset om emnet for essayet er givet, $i$ form af en bog, eller et forfatterskab, eller et sindrigt problem - forhåbentlig nok til at give det jeg skriver en retning, langt fra nok til at ane hvor det ender. Ofte forsvinder det, jeg begyndte med, og som jeg troede skulle blive stående, men som viste sig ikke at være andet end det jeg behøvede for at komme i gang: en slag suicidalt incitament, indstillet på at gå $\mathrm{i}$ opløsning og forsvinde så snart det har udspillet sin rolle.

Der må en vis mængde tekst til før jeg tør stole på det, jeg er i gang med, før jeg kan tillade mig at slappe lidt af og hygge mig med det jeg gør, den nydelse som derefter gør mig disponibel for indfald, associationer, afvigelselser $\mathrm{i}$ form af digressioner. Med sproget, nu i fuldt vigør, forsvinder kvalmen. Essayet er på vej til at finde den spirende, springende og uryddelige form jeg vil at det skal have, antændt, ikke af en pludselig frigørende tanke, men af en pludselig frigørende sætning. For det er det jeg aldrig forstår, eller i hvert fald aldrig husker, hver gang jeg skal til at begynde på et essay: at det ikke er tankerne jeg skal have fat på, men sætningerne.

\section{Den fremmede}

Jeg skriver, og som i en drøm er jeg både 1. og 3 . person, jeg både handler og ser mig selv handle. Jeg taber det jeg havde tænkt at sige, men vinder noget andet, en formulering der er som en fremmed, og som med sin fremmedhed gør mig, som forfatter, i stand til at læse den, som noget andet end den idé der ligger til grund. Jeg mærker det $i$ alt jeg skriver: det bliver fremmed for mig for at jeg skal blive $\mathrm{i}$ stand til at vurdere det.

I hver sætning er der en sætning, og $i$ fremmedheden ved det skrevne genfinder vi, forhåbentlig, en genkendelighed, en nærhed til det vi troede var tabt, fordi vi har distanceret os fra det, opgivet at forsøge at nærme os det, givet fanden i om det er 'vores' eller ej, det vi ender med, kastet vrag på en af litteraturens mest forskruede illusioner: den om tekstens ene stemme.

For er dét ikke det mest foruroligende spørgsmål vi kan stille os, og som vi aldrig, enten vi er villige til at udtale det eller ej, kan lade være med at stille: „Hvor kom de fra, de sætninger jeg skrev?““ 


\section{Sprogets havn}

I en af Peter Handkes tidlige romaner, Die Stunde der wahren Empfindung, er der en scene som i sin lidenhed, sin tilsyneladende ubetydelighed måske er let at overse, men som er en af de mest drastiske scener i nogen roman, jeg kender, selv om førstehåndsindtrykket er uskyldigt, anonymt. Eller måske netop derfor. Hovedpersonen, Gregor Keuschnig, vågner efter en urolig nat hvor han har drømt at han dræbte et andet menneske: drømmen har påvirket ham så stærkt at han føler at han må omsætte dens mærkelige indflydelse til handling - verden er ikke længere den samme, noget han føler sig kaldet til at tage konsekvensen af - og han bestemmer sig for, som det første, at forlade sin kone, han går ind på hendes arbejdsværelse hvor hun har tilbragt natten, og lader bomben springe. Han siger:

„Du bedeutest mir nichts. Ich will mir nicht länger vorstellen, mit dir alt zu werden zu müssen. Ich will nichts mehr von dir wissen."

„Das reimt sich“, sagte sie.

Ja, zu spät hatte er bemerkt, daß sich die beiden letzten Sätze reimten - und so konnte man sie nicht ernst nehmen. ${ }^{\mathrm{I}}$

Sproghandlingen er ren intention: han vil bare se at få sagt det han skal sige, men er uheldig med formuleringen i den forstand at han formulerer sig for godt, velklangen bliver prangende, alt for brilliant for meddelelsens tiltænkte chok. Sådan bliver Gregor Keuschnig offer for sprogets upålidelighed, eller rettere sagt dets egensindighed: han udleveres til en mekanisk lunefuldhed i sproget han ikke havde taget højde for. Hans frimodige tanke falder død til jorden fordi han glemte at regne med metrikkens lille djævel. Formen river tæppet væk under indholdet: det rimer, altså kan man ikke tage det alvorligt.

\section{Stedfortrcederen}

Det er blevet sagt at essayistiske momenter i romanen forurener prosaen som genre. I så fald kunne man beskrive Handkes seneste romaner som en stinkende svanesang, det essayistiske er dominerende ikke mindst $\mathrm{i}$ hovedværket fra de sidste års nær sagt maniske produktivitet, Iooo-siders romanen Mein
Jahr in der Niemandsbucht, som nærmest må regnes for en installation: at læse den er som at befinde sig inde $i$ en enorm hal, opdelt med et utal af skillevægge, en slags åbent kontorlandskab af tekster man kan slentre ind og ud af, og hvor essayet, mere end romanen, er det der binder de forskellige aflukker sammen: essayet som en digression fra den roman som egentlig skulle være skrevet.

Teksten bevæger sig fra det individuelle mod det generelle, fra fortælling til aforisme; et minimum af hændelser, et maksimum af refleksion. Og det er en refleksion som er essayistisk $i$ den forstand at den ikke behøver at angive, eller vise, selve hændelsen for at kunne reflektere over den: i stedet for går Handke den modsatte vej, lader refleksionen kredse omkring hændelser i hovedpersonens liv som aldrig er blevet berørt med rene ord, bare efterladt som en slags omrids, en kontur af noget ubeskrevet inde $i$ den jævne strøm af tanker han gør sig om det. Med udgangspunkt i nogle fă konkrete elementer - forstaden, bugten, huset, familien, vennekredsen - søger romanen mod en stadig større grad af abstraktion. I stedet for at man som læser, som man er vant til, får handlingen og må gætte sig til betydningen, får man kun betydningen, uden handlingen: selve fortællingen udgør et hulrum, beklædt med et tæt væv af fortolkning. Romanen er en meditation. Teksten bliver tekstens landskab.

\section{Den $n y$ verden}

Hovedpersonen er den samme som i Die Stunde der wahren Empfindung, ham som tyve år tidligere var presseattaché ved den østrigske ambassade i Paris og som i mellemtiden er blevet forfatter med et allerede udstrakt forfatterskab bag sig, til forveksling lig Peter Handkes, og som har trukket sig tilbage til en døsig parisisk forstad, som Handke har gjort det, for at skrive bogen Mit år ingenmandsbugten, en essaybiografisk roman bestående af I2 måneder, 365 døgn, 24 timer i døgnet. Med hud og hår vil han begrænse livsudfoldelsen kun til skrivningen. I forstaden finder han det perfekte rum for askese. Forstaden hyldes som en slags historieløst nulpunkt, en demografisk og topografisk gråzone, en hjemstavn 
uden rødder, uden noget centrum, uden noget midtpunkt, eller tyngdepunkt: en fordringsløs, karakterløs, begivenhedsløs Edens Have. Det er den utopi romaneksperimentet drejer sig omkring - det uvirksomme - og som har sit højdepunkt i protagonisten Gregor Keuschnigs maksime om ,at deltage uden at deltage." Socialt og emotionelt afholdende vil han befri sig for fællesskabets besmittelse. Samfundet er sygt, hans rolle som socialt væsen korrumperet, inficeret. Sanseapparatet, og med det hans normale dømmekraft, er brudt sammen, det må renses for derefter at kunne restitueres: tarmen må tømmes for igen at blive i stand til at optage næring. Den eneste måde at genoprette en kontakt med omverdenen på bliver derfor at lukke den ude, at isolere sig totalt, bringe sin sociale samvittighed ned til frysepunktet, for så - forsigtigt - at begynde at optage verden igen, ved at inhalere den.

Nye verden: Som at gå på en gade i nysne, hvor endnu ingen har gået undtagen en lille fugl.

\section{Usher-syndromet}

Keuschnigs omgang med verden instituerer en ekstrem sensibilitet: visheden om at hans ven er sanger, at han har en smuk sangstemme, fylder ham med intens glæde så længe vennen taler med normal stemme, på samme måde som han kan fryde sig over synet af et instrument der ikke spilles på. Men så snart instrumentet klinger, så snart sangerens stemme hæves til bare antydningen af sang, vækker det afsky. Kun når den ikke er i virksomhed glæder den ham, musikkens skønhed, kærlighedens galskab. Når noget derimod virker ved sin egenskab eller sit talent, det vil sige i det øjeblik det ophører med at være latent, et register af ubrugte egenskaber, og i stedet bliver virkeliggjort som en hændelse, som en konsekvens, bliver det modbydeligt: udfoldelsen vækker afsky. Det eneste han rigtig kan nyde er tingenens iboende skønhed: som en overfølsom Roderick Usher er Keuschnig afhængig af tingenes passivitet for at kunne tåle dem. Hans oplevelse og forståelse af dem forudsætter med andre ord at de ikke retter sig mod ham, at de ikke henvender sig til ham, ikke taler til ham. Sådan står alle ting og alle mennesker for Keuschnig kun som fuldbragte i deres uvirksomhed, i deres slumrende potentiale, på samme måde som han selv ønsker at deltage som en ikke-deltagende, at gribe ind uden at gribe ind, at være et menneske ved ikke at leve sig ud, at eksistere i verden som et vidne: en aktiv passivitet. Kun opfyldt af tingen, eller mennesket, eller begæret, intakt. Kun uvirksom og stillestående kan han, Keuschnig, mennesket, være i verden som den han er. At handle, at realisere bliver synonymt med at ødelægge, at tømme for indhold, at slippe ånden fri

\section{TALENT}

LATENT

Essayet som et forsøg på at fange tanken in spe, at bevare en form-for-formløshed.

\section{Let it not be}

Faktisk skriver Keuschnig ingenting i løbet af hele bogen, og sådan bliver hele den monstrøse tekstmasse i praksis en beskrivelse af en bog mens den bliver til, som en ekstra bog uden på den bog der fortælles om, en bog som alligevel ikke bliver skrevet, eftersom Keuschnig, dens forfatter, er optaget af at skrive historien om hvordan den bliver til. Sådan bliver Mein Jahr in der Niemandsbucht i konkret forstand, og til trods for sit sideantal, en bog om ingenting: en ingenmandsbog. Vi făr aldrig set hvad Keuschnig skriver, vi fảr bare hele tiden at vide at han gør det, hvordan han gør det, hvorfor han gør det, $i$ en slags skrivningen indre - eller ydre - monolog. Denne konsekvente indirekthed bliver en måde at undgå at udlede en konsekvens. Selv i forsoningens midnatstime, romanens grandiose afslutningsceremoni, da alle vennerne samles i ingenmandsbugten, mangler der én: sangeren, han som ville have velsignet genforeningen med sin sang, men som selvfølgelig er desto vigtigere - for Handke - som mangel, for så undgår Keuschnig endnu en gang at fuldføre. Den endelige konsekvens af forbrødringen udebliver, fællesskabet er ikke fuldtalligt, det ufuldstændige står ved magt. 
Hvorfor? Er det fordi han - Keuschnig? Handke? dermed håber at holde for tællingen, årsberetningen fra ingenmandsbugten hvis udeblivelse Keuschnig siges at være i færd med at nedtegne, 'tilbage i sig selv', at hindre den i at tømmes ved at blive skrevet, at værne den mod at ødelægges ved at blive fuldført, og så blive læst? At Keuschnigs beretning om beretningens tilblivelse $\mathrm{i}$ virkeligheden er et værn mod dens opløsning, dens formløsrivelse og destruktion, $i$ håb om at kunne bevare den, hermetisere den $\mathrm{i}$ en fuldkommen og ubrugt form, forsikre sig om at den aldrig bliver skrevet, aldrig bliver læst, aldrig bliver til noget, men i stedet forbliver i det latente, det uformulerede, $\mathrm{i}$ det præsumptives umælende paradis, på samme måde som forfatteren måske altid vil se med rædsel på at skulle afslutte den tekst han er ved at skrive, som er en rædsel for at opgive mulighederne for forandringer, forbedringer, forklaringer, fordi han ved at så vil præmisserne være sat for aldrig mere at kunne ændres, at teksten i samme øjeblik ophører med at være en mulighedernes form, sådan som den ligger foran ham, færdig, i brutal uforanderlig kontrast til flygtigheden, formeligheden og ubestemmeligheden $i$ et værk under tilblivelse, dette som et unævneligt ideal i dyb modsætning til omverdenens krav om henvendelse, kommunikation, deltagelse, et ideal Handke med den essayistiske kæmpetekst har forsøgt (paradoksalt) at lægge frem for offentligheden: drømmen om at forblive sådan, ufuldendt, uvirkeliggjort, for evig og altid under tilblivelse.

Essayet som et forsøg på at reflektere det endnu ikke fuldt ud tænkte.

\section{Stream-of-consciousness}

Essayet har faglitteraturens logiske struktur epifytisk på skønlitteraturens løse tekstkultur, og på den anden side fungerer essayet, ikke først og fremmest som tænkning, men som en beskrivelse af tænkningens forløb: en stream-of-consciousness mere end den romanfiktion som i så mange år har prøvet at efterligne den. Ræsonnementet făr ben at gå på i et mærkeligt spændingsfelt mellem systematikken og det rene tankespind, provokeret af et permanent udestående mellem konstruktivisme og intuition: essayet river sig løs fra metodikken, for så at finde tilbage til den, for derigennem at bygge sig op til en ny løsrivelse. Gentagne brud, gentagne tilbagefald. Således repræsenterer essayet, i bedste fald, en distinkt gengivelse af tankens vaghed. Eller omvendt. Det præsenterer ikke tanken, men udvikler den, kaster den frem og følger den, uvist hvorhen.

\section{Error}

Essayet er ingen mirakel-genre, sådan som mange af dets apologeter synes at føle sig forpligtet til at mene: essayet som selve superteksten som assimilerer alle øvrige genrer i en slags intellektualpoetisk tour de force. Sådan er det selvsagt ikke. Essayet er ikke lydefrit, selv om det er aldrig så fristende, og for nogen uimodståeligt, ikke mindst når man samles for at samle tankerne om en definition af 'det gode essay', at hengive sig til panegyrisk hyperventilering. Tværtimod vil jeg sige at essayet er den mest lydefulde af alle genrer, og derfor ser jeg det som nok så frugtbart at definere det ved dets fejl og mangler som ved dets indlysende fortrin, at lægge vægt på essayets svagheder, for derigennem, i næste omgang, at manøvrere disse op til overfladen, stille dem på linje med de åbenbare kvaliteter, som følge af en overbevisning - min - om at kunsten - essayet medregnet - udtrykker sig lige så vel gennem svaghed som gennem styrke, at den er en bevidnelse af vor menneskelighed i lige så høj grad, den tanke som ikke griber fat som den tanke som udøver sit embede med brillians. Essayet er urent, og kan, ved sin blotte eksistens, dermed ikke gøre en ende på debatten om hvad der er kunst og hvad der ikke er litteratur.

Når jeg tænker mig om kan jeg ikke komme på noget jeg finder mere uinteressant end virtuositet.

Ikke astetisk produktivitet, men heller ikke $i$ strengeste forstand religiøs

Med Kierkegaards schizofrent rigide skelnen mellem det religiøse og det æstetiske sættes (I843-I855) begreb på det uudsigelige, tanken som ikke kan udtrykkes, som ikke kan gå omveje, og som ikke kan 
forklares, og som kun kan angives negativt, med det negativt hjælpende, som er det æstetiske bedrag, som først stryger den indbildt kristne med hårene, for så, sagte og sokratisk, at lirke ham ud af hans vildfarelse, forberede ham, og udruste ham, til den erkendelse ingen som helst velment prædiken kan overtale ham til, fordi den eneste måde at forstå den på er ved at erfare den. Den religiøse frelser kan følge ham til Perleporten, men ikke længere. Det religiøse kan ikke artikuleres uden at pulveriseres, samtidig med at den æstetiske - indirekte - meddelelse aldrig kan favne hele tankens spektrum. Amplituden har en grænse, selv for den mest indtrængende overtalelseskunst. Vi kan føres op til, indtil... det sidste spring må vi selv gøre.

Hos Kierkegaard handler al udsigelse om dette, hver eneste sætning er som en iscenesættelse af dette tab, som al udsigelse repræsenterer, i forhold til den storhed $\mathrm{i}$ tanken som udsigelsen aldrig ophører med at ville nå op til. Samtidig demonstrerer Kirkegaard bevidst, ubevidst - med sin skrift at det aldrig kun er det ene eller det andet, at der altid er en rest af det andet $\mathrm{i}$ det ene. Den direkte meddelelse er ikke mulig som andet end en idealitet, en tanke, født af tanken. Anskueliggjort på hvilken måde? Jo, gennem Kierkegaards knitrende ornamentale klosterprosa, det vil sige: gennem en indirekte-altfor-indirekte tale. Det direke er det uudsigelige. Det direkte er - må være, som det eneste - kontakt med Gud. Det indirekte er det menneskelige, med eller uden Gud. Ujævnheden, uefterretteligheden, utilstrækkeligheden, hullerne, manglerne, fejlene ved alle vore udsagn er menneskets signatur på noget som i sit væsen stræber efter perfektion.

\section{Kleinkunst}

Essayet står, med sine mange mangler, i konstant opposition til de store linjers tænkning. Vi kan lægge oplysningstiden, renaissancen og positivismen bag os ad infinitum, vi baserer alligevel vor humanistiske og intellektuelle forankring $i$ en forestilling om progression, dannelse, en taktfast hævelse af bevidsthedsniveauet. Hundrede gange om dagen bedrages vi af det betydningsfulde. Men hvis vi tænker os om, spiller det da så afgørende en rolle som vi tror, eller tager for givet, om vor tænkning bevæger sig fremad eller sættes ti år tilbage? Om litteraturvidenskaben konstituerer endnu en Hamlet? Om Kong Ødipus vendes til at handle om forældrenes begær, ikke sønnens? Om det er hansmagnusenzenberger eller claudiomagris som kommer bedst ud af den fjensynstransmitterede hanekamp om rigets - dvs. Tysklands - tilstand? Om definitionen af det gode essay bliver en vi kan slå os til tåls med? Det er jo et træk ved vor tid at selv byfornyelsen er blevet hævet til at være en intellektuel disciplin. Vor tid er ikke posthistorisk, eller postmoderne, eller transglobal. Den er... alt på én gang, det vil sige ingenting, så mættet med teser at ingen tanke kan rokke ved nogen tanke, så proppet med nytækning at ingen fornyelse længere er mulig. Musils pose - som ændrede form for hver ny sandhed man proppede ned i den, samtidig med at den bliver fastere og fastere - er revet $i$ stumper og stykker. Kritikken er en profession, for tiden rettet mod nationalstatens myter, med IT-teknologien som ballast. Per februar 1998 tales og skrives der så meget om kulturel identitet blandt vestens intellektuelle at der ingen er som forstår hvad den er, og snart ingen som er $\mathrm{i}$ besiddelse af den.

Prestige er en ledestjerne. Store ord er big business. Så længe det varer. Politikken er i forste række en næring for alle som gennemskuer den og som daglig fremfører deres dræbende analyser og erklærer den for spilfægteri, bigotteri, patoshysteri. Alt småtteriet, derimod, har et forbløffende talent for overlevelse - i modsætning til monumenterne, som pulveriseres hvis de forst vælter overende - de hæver sig ikke over, men kravler under, uantastet af skiftende tider, de store omvæltninger. Bagatellerne, de usle og ubetydelige, er sandsynligvis det eneste som udgør nogen form for kontinuitet $i$ det moderne menneskes liv. Det mest afgørende ser ofte så ubetydeligt ud. Robert Walser er et monster. Og sådan har det måske altid været? Måden man trykker tandpastatuben på har magt til at kuldkaste kærligheden. Bittesmå myrer kan æde bjælkeloftet $i$ et hus så det styrter sammen uden at styrte sammen, det står bare og venter på et vindpust. 
Essayet er bagatellernes gudfar.

\section{Non serviam}

Jeg vil hævde, eller i hvert fald prøve påstanden, at essayet er en mentalitet mere end en genre. Der findes en række tænkere, som måske begynder med Max Stirner, går videre over Nietzsche, Strindberg, surrealisterne, frem il en Georges Bataille og en Maurice Blanchot - essayister mere end filosoffer for hvem tænkningen i sidste instans er en bevægelse væk fra tanken, en tænkning som umærkelig drejer væk fra sig selv, som gør en æressag af at underkende sig selv: teksten bliver en øvelse $i$ at undertrykke tankens konforme progression, tvinge den i knæ, for gennem dens nederlag at forsøge at rydde pladsen for noget andet - eller ingenting åbne den, opnå en gennemskinnelighed $\mathrm{i}$ tankens tætte masse, uden nødvendigvis at vide hvad der kommer tilsyne, eller bliver dens erstaming; og som har det til fælles at de i deres yderste intellektuelle anstrengelse fremelsker en form for tankens primivitet, eller endelig: tankens ophør. Overskridelse i form af ødelæggelse. Ophøjelse i form af detronisering.

Rammerne sprænges. Hvorfor? Fordi logikken, metodikken, det filosofiske eller intellektuelle ræsonnement, i det øjeblik det er ført så langt det kan komme, ikke fremstår som fuldbragt, men tværtimod viser videre, ud over sine egne grænser, mod noget uudsigeligt, som det selv er ude af stand til at favne. Det filosofiske eller intellektuelle ræsonnement bruger sproget på en sådan måde at man stilles $\mathrm{i}$ et forpligtende forhold til begreberne, eller det begrebslige: sådan vil det mål man har sat sig for øje altid modsætte sig den slutning man er i stand til at drage, $i$ hvert fald når ræsonnementet foregiver at besvare sin egen undersøgelse, i det afgørende øjeblik kommer man altid til kort. Sproget, brugt i sin yderste, mest finstemte konsekvens, bliver et udtryk for dets utilstrækkelighed.

Et udtryk for dets utilstrækkelighed som hos disse tænkningens faldne engle som man lidt pompøst kunne kalde dem, bærer bud om en slags omvendt manscendens, en overgang fra vished til ikke-vished, visdom til ikke-visdom, fra logos til loco, fra svada til nada. Det er derfor det essayistiske og det aforistiske, fremfor det rent filosofiske, som hersker i disse tekster, fordi det giver dem den åbenhed og tvetydighed de selv - teksterne - sætter som en betingelse for deres heroiske forsøg: at befri udsigelsen fra begrebernes tvang, at forhindre ræsonnementet $i$ nogensinde at fremstå som fuldbragt. Angreb er det bedste forsvar. Jo længere ræsonnementet føres, desto inere går det $\mathrm{i}$ opløsning, bliver til ingenting, til sidst, som hos Blanchot, en gråbleg overgang til intet, som spioneventyrets selvdestruerende telegrammer, meddelelsen som går op i røg idet den læses. Hvor teksten skulle have nærmet sig sin konklusion, fades den ud.

Kierkegaard er også i berøring med denne række, dog med et andet temperament og en væsentlig anderledes motivation. Men det er den sammen underliggende drivkraft, den som hos Kierkegaard făr sit pas stemplet med et af filosofihistoriens mest strålende paradokser: at tanke sig ind i enfoldigheden. Men hele bevægelsen er i sit væsen paradoksal, fordi idealiseringen af det ikke-reflekterede, ikke-tænkningen, er betinget af et avanceret, kompliceret, og subtilt intellektuelt ræsonnement. Afsporingen muliggøres kun hvis det $\mathrm{i}$ første omgang er lykkedes at få tanken ind på det rette spor. Dette er essayets manddomsprøve: man må op på et vist niveau, før man kan lade det flyde og forvitre.

\section{Tankens letsindighed}

Som sværdet $\mathrm{i}$ den gordiske knude har essayet letsindigheden som sit forløsende greb: en peripeti til fordel for det mindre betydelige...

Letsindigheden er en digression...

Digressionen er letsindig, fordi den er utilsigtet, som det hurtige penselstrøg maleren ved han aldrig vil kunne gentage, og som det er umuligt at kopiere...

Digressionen eksisterer ikke før den er skrevet... 
Digressionen er essayets aforisme: den kommer med en art lethed, ved siden af den omhygelige argumentation man er ved at bygge op. Den er ilten som redder mig når min tænkning er ved at lide kvælningsdøden. I digressionen slapper jeg af, ånder let, ubesværet. Nu bliver der taget hånd om mig, digressionen gør arbejdet for mig, efter jeg har måttet trække læsset alene. Udkørt og lykkelig - eftersom det at være at være udkørt næsten altid er at være tilfreds - lægger jeg mine ambitioner, min ærgerrighed til side, lukker øjnene, lægger hovedet tilbage og lader tankerne flyde...

Senere ser jeg at det var digressionen - afslapningsøvelsen - som blev essayets bærende element...

Letsindigheden har en fantasi som overgår forfatterens opfindsomhed...

Digressionen, eller letsindigheden, vil som regel være så lidt gennemtænkt at den aldrig rigtig bliver et problem, diskrepansen mellem tanke og ytring. Den - tanken - bliver til idet den bliver skrevet, og har på den måde ikke nogen fikseret intention om at blive målt $\mathrm{i}$ forhold til, fundet for let $\mathrm{i}$ forhold til. Tanken bliver fri ved at overlade det til sproget at bestemme hvad den skal blive til...

Det er umuligt, selv for forfatteren at blive skuffet over en letsindighed...

Digressionen redder mig fra den trodsige vilje jeg lægger bag den idé som er udgangspunktet for det jeg skriver, en vilje som, hvis jeg udelukkende skulle have lystret den, ville have gjort hver eneste tekst til krøbling...

Løsningen på et problem består som regel $\mathrm{i}$ at opdage at det ikke er noget problem, og sådan kommer man også $i$ essayet før eller senere til det punkt hvor man holder op med at plage sig selv med spørgsmålet Hvordan omsatter jeg denne tanke i ord, og lægger sine bekymringer fra sig og spørger: Hvilken tanke vil opstår af disse ord...
Letsindigheden er en udjævning, som med digressionens velsignelse, udligner forskellen mellem indfald og dybsindighed. Det spontane sidestilles med det velovervejede... flygtighed med det bestandige... det lette med det tunge... hurtighed med langsomhed... det smagfulde med det smagløse... det gode med det onde...

Letsindigheden er en opvågning $\mathrm{i}$ form af en pludselig kølig regn. som den strømmende skraverende regn i Kurosawas film, som næsten altid kommer mod slutningen, når katastrofen er en kendsgerning, når bastionerne er lagt $i$ grus: så begynder det altid at regne hos Kurosawa, en vedvarende skylregn som ligesom fylder hele billedet og gør alt lige fladt, perspektivløst. Regnen ophæver hierarkiet i tragedien, forvandler scenen til en eneste stor regntung flade hvor narren og vasallen sættes på sammen plan som generalen. En udjæuning som er en befrielse...

Den æstetiske bevidsthed vil aldrig være bevidst om alt hvad den gør. Hvert kunstværk har en uefterrettelighed, også i forhold til den tanke - kunstnerens - som ligger bag: den lader sig ikke tænke fuldt ud, og må derfor virke gennem det utilsigtede, det som opstår idet man skriver eller maler...

Essayet er at være tanke, at være refleksion, men at være det $\mathrm{i}$ form af kunst...

På dansk ved Marianne Ping Huang

Note

I. Af hensyn til spillet mellem Gregor Keuschnigs villen og gøren, bringes citatet på originalsproget. 